\title{
Endüstri 4.0 Çağında Yükseköğretim Kurulumları İçin Tedarik Zinciri Yönetiminde Bir İş Zekâsı Karar Destek Sistemi Uygulaması*
}

\author{
Implementing A Business Intelligence Decision Support System in Supply Chain \\ Management for Higher Education Institutions in The Age of Industry 4.0
}

\author{
Muhammet DAMAR ${ }^{1}$
}

$\ddot{O} z$

Türkiye'de 2021 y1lına gelindiğinde iki yüzün üzerinde üniversitenin eğitim ve öğretim faaliyeti gösterdiği görülebilir. Yükseköğretim kurumları Türkiye'nin barındırdığı genç nüfus da dikkate alındığında ülke geleceği için kritik ve önemli bir noktada yer almaktadır. Bu anlam üniversite kavramının tarihsel süreç içerisinde geçirdiği dönüşüm ve günümüzdeki kritik değeri değerlendirildiğinde ne kadar önemli olduğu görülebilir. Fakat son yıllarda hızla açılan yeni üniversiteler, Türkiye'nin gelişmekte olan kıt kaynaklara sahip bir ülke olduğu gerçeği, yükseköğretim kurumlarında bütçe yönetimini ve harcamaların etkin kullanımının önemini daha da ortaya koymaktadır. Çalışma bu amaçla, bir üniversitelerin satın alma süreçleri için bir karar destek modeli ortaya koymakta ve uzun süre satın alınan ve farklı birim harcamalarının etkin yönetimi için iş zekası modelini çözüm olarak sunmaktadır. Ortaya konulan çalışma bir üniversite için uygulanabilirliği üzerine kurgulanmış ve demo veriler ile gerçekleştirilen raporlama aracı ile olası kazanımları üzerinde bir değerlendirmede bulunulmuştur. Çalışma bu yönüyle kendi gelirleri ile birlikte kamu bütçesinden faydalanan yükseköğretim kurumlarının etkin bütçe yönetimine dikkat çekmektedir. Gerçekleştirilen uygulamanın kamu kurumlarının hem iç hem de dış denetim süreçleri için bilişim sistemlerinin etkin kullanımı için örnek teşkil edecektir. Literatürde gerçekleştirilen ulusal ve uluslararası tartışmalar ile yükseköğretim kural koyucularının iş zekası gibi güncel teknolojileri kullanarak nasıl daha etkin veri analizi yapabileceği ve veri yönetimi ile etkin kurum yönetimi sağlanabileceği hususunda değerlendirme sunmaktadır.

Anahtar Kelimeler: İş zekâsı, üniversite, bütçe yönetimi, karar destek, satın alma süreci, talep yönetimi

\begin{abstract}
By 2021, it can be seen that more than two hundred universities are engaged in education and training activities in Turkey. Higher education institutions are at a critical and important point for the country's future, considering the young population of Turkey. When the historical development of the concept of university and its crucial value now are considered, it is clear how important this meaning is. However, the necessity of budget management and effective use of expenditures in higher education institutions is highlighted by the rapid opening of new universities in recent years, as well as the fact that Turkey is a developing country with limited resources. The study proposes a decision support model for a university's purchasing operations, as well as a business intelligence model as a solution for the successful management of longterm and different unit expenditures. The study was built on its applicability for a university and an evaluation was made on the possible achievements with the reporting tool made with demo data. With this aspect, the study draws attention to the effective budget management of higher education institutions that benefit from the public budget with their own revenues. The implementation will set an example for the effective use of information systems for both internal and external audit processes of public institutions. With the national and international discussions in the literature, it provides an evaluation on how higher education policy makers can make more effective data analysis by using up-to-date technologies such as business intelligence and provide effective institution management with data management.
\end{abstract}

Keywords: Business intelligence, university, budget management, decision support, purchasing process, demand management

* In this article, the principles of scientific research and publication ethics were followed. / Bu makalede bilimsel araştırma ve yayın etiği ilkelerine uyulmuştur.

\footnotetext{
${ }^{1}$ Muhammet DAMAR

ORCID ID: 0000-0002-3985-3073

$\begin{array}{ll}\text { Geliş Tarihi/Received } & : 14.09 .2021 \\ \text { Kabul Tarihi/Accepted } & : 27.10 .2021 \\ \text { Çevrimiçi Yayın/Published } & : 28.10 .2021\end{array}$
}

Öğr. Gör. Dr., Dokuz Eylül Üniversitesi, Rektörlük, Bilgi İşlem Dairesi Başkanlığı, İzmir, Türkiye, muhammet.damar@deu.edu.tr

Lecturer Dr., Dokuz Eylul University, Rectorate, Department of Information Technologies, Izmir, Turkey, muhammet.damar@deu.edu.tr

Makale Atıf Önerisi /Citation (APA):

Damar, M. (2021). Endüstri 4.0 Çağında Yükseköğretim Kurulumları İçin Tedarik Zinciri Yönetiminde Bir İş Zekâsı Karar Destek Sistemi Uygulaması. Izmir Sosyal Bilimler Dergisi, 3 (2), 144-158. DOI:10.47899/ijss.20213204 


\section{GiRiş}

Türkiye'de 2021 yılına gelindiğinde iki yüzün üzerinde üniversitenin eğitim ve öğretim faaliyeti gösterdiği görülebilir. Türkiye'de 3.114 .623 önlisans, 4.676.657 lisans, 343.569 yüksek lisans ve 106.148 doktora öğrencisi bu kurumlarda öğrenim görmektedir. Türkiye'de 4 vakıf meslek yüksekokulu, 74 vakıf, 129 devlet üniversitesi olmak üzere toplamda 207 üniversite bulunmaktadır. Bununla birlikte 207 üniversitede 31.495 profesör, 18.682 doçent, 41.129 doktor öğretim üyesi, 38.019 öğretim görevlisi ve 52.118 araştırma görevlisi olmak üzere toplamda 181.443 akademik personel ile Türk Yükseköğretim Sistemi akademik faaliyetlerini yürütmektedir (YBYS, 2021). Yükseköğretim kurumlarına 2020 yılında yapılan hazine yardımı 30.769.078.000 TL olmak üzere toplam ödenek 33.120 .407 .000 'dır. Türkiye İstatistik Kurumu verilerine göre Türkiye'nin 2020 yılı nüfusu 83.614.362 kişidir (TÜiK, 2021). Toplam nüfusun $\% 9,86$ 'sı yükseköğretim kurumlarında eğitim öğretim faaliyetlerini sürdürmektedir. İlgili rakamlar Türkiye'nin genç ve dinamik nüfusunun şekillenmesinde, ekonomiye kazandırılmasında yükseköğretim kurumlarının kritik önemini ortaya koymaktadır.

Literatürde yükseköğretim kurumlarının finansmanı ile ilgili pek çok tartışma yapılmaktadır (Teker ve Teker, 2012; Söyler ve Karataş, 2011; Akça, 2012; Leslie ve Brinkman, 1988; Weifang, 1991; Nerlove, 1975). Bu konuda Türkiye'de geçerli olan yukarıdaki 2020 bütçe ve ödenekleri ile Uslu ve Ertaş (2018)'ın çalışmalarında belirttiği gibi kamu üniversitelerine devlet tarafından hazineden ayrılan bütçelerdir. Bu bütçeler için kurumların stratejik eylem planları önem teşkil etmekte, kurumlar yıllık veya üç-beş yıllık uzun soluklu planlamaları ile ödeneklerini almaktadır.

Türkiye gibi gelişmekte olan bir ülkenin gelişirken, genç dinamik insan kaynağını ekonomiye, tüm sanayi dallarına, eğitim öğretim faaliyetlerine katalize etki yatacak ve kendini gelişmiş ülkeler seviyesine çıkaracak şekilde kurgulaması zorunludur. Yükseköğretim kurumlarının sürdürülebilirliği için ekonomik kaynaklardan en ideal şekilde faydalanmaları zorunlu bir durum olarak karşımıza çıkmaktadır. Özellikle son yıllarda hızla açılan yükseköğretim kurumları, üniversitenin finansmanı ve kamu veya özel kaynaklardan elde edilen bütçenin yükseköğretim faaliyetlerinde en ideal şekilde kullanılması arayışını da birlikte getirmiştir.

Yükseköğretim kurumları, Türkiye'nin barındırdığı genç nüfus da dikkate alındığında, ülke geleceği için kritik ve önemli bir noktada yer almaktadır. Bu anlam, üniversite kavramının tarihsel süreç içerisinde geçirdiği dönüşüm ve günümüzdeki kritik değeri değerlendirildiğinde daha da önemli olduğu görülebilir. Fakat son yıllarda hızla açılan yeni üniversiteler, Türkiye'nin gelişmekte olan kıt kaynaklara sahip bir ülke olduğu gerçeği, yükseköğretim kurumlarında bütçe yönetimini ve harcamaların etkin kullanımının önemini daha da ortaya koymaktadır. Tüm bu gerçekler tasarruf ve bütçe ödeneklerinden en ideal şekilde faydalanma gereksinimini ortaya koymaktadır.

İçinde bulunduğumuz çağ bilginin hızla dönüştüğü, endüstrinin kabuk değiştirdiği, bilgi ve iletişim teknolojilerinin nimetleri ile insansız hale geldiği, bilgi sistemlerinin ve kurum faaliyetlerinin yürütülmesinde süreçlerin dijitalleştiği ve dijitalleşmenin öneminin arttığı bir çağdır. Üretim sektörü için ise endüstri 4.0 çağı olarak ifade edilen pek çok farklı sistemin ve aracın birbiriyle ve dış paydaşlar ile etkileştiği dijital bilgi çağıdır. Endüstri 4.0 çağı, tüm sektörleri ilgilendiren ekonomik kalkınma ve yenilik faaliyetleri için kritik bir unsurdur (Hsu ve Yeh, 2017). Ghobakhloo (2018), şirketlerin yoğun rekabette rekabet avantajı elde etmek istiyorlarsa dördüncü sanayi devrimine uyum sağlamaları gerektiğini ifade etmişlerdir. Lee ve diğerleri (2013), iş hayatındaki teknolojik yeniliklerin, şirketlerin kısa ve vadeli performans düzeyini, ayrıca sürdürülebilirliğini etkilediğini ifade etmişlerdir. Bu durum sadece işletmelerin bir gerçeği değildir, aynı durum yükseköğretim kurumları için de geçerlidir.

Çalışma bu amaçla, üniversitelerimizde gerçekleştirilen satın alma süreçleri için bir karar destek süreci modeli ortaya koymakta ve uzun süre tedarik edilmiş ürün bilgileri üzerinde veri analizi imkanı sağlamakta, satın alınan ve farklı birim harcamalarının etkin yönetimi için iş zekası modelini çözüm olarak sunmaktadır. Yükseköğretim kurumları büyüklüklerine göre pek çok fakülte, enstitü, meslek yüksekokulu ve araştırma merkezleri gibi farklı birimleri içinde barındırmaktadır. Bu birimler oluşturdukları takdirde kendi döner sermaye kaynakları ile veya birim ile genel bütçe kaynakları olmak üzere farklı kaynaklar ile birim intiyaçlarına dönük tedarik süreçlerini çözebilmektedir.

Çalışma özgün ve yenilikçi yönüyle değerlendirildiğinde, üniversite bütçelerine odaklanan farklı çalışmalar (Bal, 2015; 2016; Demirel, 2015; Erüz, 2005, Fırat, 2016;Karacan, 2010; Kurnaz, 2010;Uslu and Ertaş, 2018; Yazıcı, 2015) gerçekleştirilmiş olsa da satın alma taleplerinin toplanması ve bunun bir komisyon değerlendirmesine imkan veren, geçmişe dönük verilerin saklandığı, saklanan veriler üzerinde analiz yeteneğinin kazanıldığı ve sonraki etapta bunu iş zekası gibi çok güncel ve yükseköğretim kurumlarında kullanımının gerekli görüldüğü bir teknoloji ile raporlayan, veri analizi imkanı sağlayan uygulamanın 
geliştirildiği bir çalışmaya rastlanılmamıştır. Çalışmanın bu bağlamda, geliştirilen sistem hakkında teknik bilgilerin paylaşılması, deneyim ve tecrübelerin açıklanması ve kapsamlı literatür bilgisi içermesi açısından bu alanda çalışan araştırmacılara, üniversite yöneticileri ve kural koyucular için değerli bir analiz ve sunum ortaya koymaktadır.

Ortaya konulan bu çalışma bir üniversite için ürün tedarik süreçlerinde taleplerin denetim altına alınmasını, sorgulanmasını, kayıt altına alınmasını, geçmişe dönük birim ve kurum geneli tedarik edilen ürünlerin kayıtlarının değerlendirilebilmesini, inceleme ve analiz etme imkanı sunmaktadır. Çalışmada demo veriler ile gerçekleştirilen raporlama aracı ile olası kazanımları üzerinde bir değerlendirmede bulunulmuştur. Çalışma bu yönüyle kendi gelirleri ile birlikte kamu bütçesinden faydalanan yükseköğretim kurumlarının etkin bütçe yönetimine dikkat çekmektedir. Gerçekleştirilen uygulamanın kamu kurumlarının hem iç hem de dış denetim süreçleri için bilişim sistemlerinin etkin kullanımı için örnek teşkil etmektedir. Literatürde gerçekleştirilen ulusal ve uluslararası tartışmalar ile yükseköğretim kural koyucularının iş zekası gibi güncel teknolojileri kullanarak nasıl daha etkin veri analizi yapabileceği ve veri yönetimi ile etkin kurum yönetimi sağlanabileceği hususunda değerlendirme sunmaktadır.

Çalışmada sırasıyla; birinci bölümde, yükseköğretim kurumları ve finansmanı değerlendirilecek, ikinci bölümde yükseköğretim kurumları için iş zekâsı teknolojisinin önemi ve olası kullanım alanları üzerinde bir değerlendirmede bulunulacak, üçüncü bölümde çalışmanın yöntemi ve araştırma soruları açıklanacak, dördüncü bölümde elde edilen bulgular ve uygulama üzerinde açıklamalarda bulunulacak, son bölümümüz olan tartışma, sonuç ve öneriler bölümünde ise, araştırmada elde edilen literatür bilgisi, saha çalışmasından elde edilen deneyim ve tecrübe, sistemin kurgulanması süreci ve iş zekası ile raporlanması süreci, olası senaryo ve çıktılar çerçevesinde tartışılacak, sonuçlandırılacak ve sonraki çalışmalar ve elde edilen deneyimler ışığında araştırmacılara öneriler sunulacaktır.

\section{YÜKSEKÖĞRETIM KURUMLARININ FINANSMANI ve MALZEME TEDARIK SISTEMI}

Kamu kurumları faaliyetlerini sürdürebilmek için devlet tarafından kurumlara göre değişiklik göstermek ile birlikte çeşitli oranlarda ödenek almaktadır. Alınan bu ödenekler mal ve hizmet giderleri için kullanılmaktadır. Bu başlık altında yükseköğretim kurumlarını finansmanı ve kurum ihtiyaçlarına dönük malzeme tedarik süreci iki başlık altında değerlendirilmektedir. Bu sayede gerçekleştirilen çalışmanın öneminin daha iyi ortaya konulacağı düşünülmektedir.

\subsection{Yükseköğretim Kurumlarının Finansmanı ve Bütçe Yönetimi}

Türkiye'de her ne kadar yükseköğretimin finansmanı konusu son yıllarda tartışılsa da (Teker ve Teker, 2012; Söyler ve Karataş, 2011; Akça, 2012) doksanlar ve iki binli yıllarda dünyanın değişik bölgelerinde bu konu tartışılmaya başlanmıştır (Leslie ve Brinkman, 1988; Weifang, 1991; Nerlove, 1975). Günümüzde de bu kurumların finansmanı ve faaliyetleri (Carnoy vd., 2014; Hauptman, 2007; Weisbrod ve Asch, 2010) tartışılmaya devam etmektedir. Sam (2011, s.2), gelişmekte olan ülkeler için yükseköğretim finansmanının büyük oranda hükümet tarafından ve alınan vergiler aracılığı ile karşılandığını belirtmiştir. Uslu ve Ertaş (2018, s.979-980), Türkiye'de yükseköğretim kurumlarının faaliyetleri için gerekli bütçenin büyük bir kısmının devlet tarafından karşılandığını, küçük bir bölümünün öğrencilerden alınan kayıt ücretleri veya üniversitelere gerçekleştirilen bağışlar aracılığı ile olduğunu ifade etmişlerdir. Ayrıca, son yıllarda yükseköğretim kurumlarının kendi kaynaklarını oluşturmaları, araştırma ve geliştirme faaliyetleri ile üniversite sanayi işbirlikleri ile alternatif finansman kaynakları oluşturmaları gereğini vurgulamışlardır.

Kendi kaynaklarını oluşturmuş, araştırma ve geliştirme faaliyetlerine önem vermiş, teknoparklar ve çeşitli projeler ile alternatif finansman kaynağı yaratabilmiş üniversitelerin önemi daha da artırmıştır. SBB (2021) verilerine göre, yükseköğretim kurumlarına 2020 yılında ayrılan bütçeler içinde hazine yardımı 30.769.078.000 TL ve 2.351.329.000 $\mathrm{TL}$ ise öz gelir olmak üzere toplam ödenek 33.120.407.000'dır. Bu referans veriye göre Türkiye'de yükseköğretim kurumlarının sürdürülebilirliği için istenen finans kaynağının \%7,1'ini sadece öz geliri ile elde edebildiği görülmektedir. Elde olan bu oranın oldukça düşük bir oran olduğu, Türkiye'de yükseköğretim kurumlarının kamu kaynakları ile sürdürülebilir hale geldiği, kendi kaynakları ile yaşamsal faaliyetlerini sürdüremedikleri, dolayısı ile elde ettikleri kamu kaynaklarının etkin kullanım ve yönetiminin önemli hale geldiği ayrıca ifade edilebilir.

Kamu kurumları yıllık ve dönemsel olarak mal ve hizmet ihtiyaçlarını giderebilmek için oluşturdukları bütçeler ile faaliyetlerini yürütmektedir. Dülger ve diğerleri $(2012$, s.4) klasik anlamda bütçeyi, "devlet bütçesi kamu kurum ve kuruluşlarının, belirli bir dönem için gelir ve giderlerini tahmin eden, bunların uygulanmasına önceden izin veren hukuki bir dokümanıdır" şeklinde tanımlamıştır. Bütçe hakkı konusunda ilk adımı atan ülke İngiltere'dir (Kurnaz, 2010, s.31). Yukarıda da ifade edildiği gibi devlet üniversitelerinin bütçelerinin büyük bir bölümü devlet tarafından 
karşılanmaktadır. Fırat (2016, s.322), devlet üniversitelerine sunulacak bütçe diğer kamu kurumlarında olduğu gibi yasama organı tarafından onaylamakta, yürütme organı ise kamu organlarınca mal ve hizmetin üretilerek gelirlerin toplanmasını sağladığını, olası bütçe veya usullere ilişkin usulsüz veya anlaşmazlıklara dönük durumlar ise yargı tarafından çözüldüğünü ifade etmiştir.

Tüm kamu kurumları için harcama yönetimi ve bütçe yönetim sistemi kritik bir araç olarak karşımıza çıkmaktadır (Yazıcı, 2015, s.90). Karacan (2010, s.176)'a göre, son yıllarda yaşanan büyük krizler, kamu sektörlerini de etkilemiş, geleneksel bütçe sistemi sorgulanır hale gelmiştir. Kamu kurumlarında bu durum performans yönetimi ve stratejik yönetim gibi reformlar gündeme getirmiştir. Bu durum performans esaslı bütçeleme anlayışına kamu kurumlarının girmesini neden olmuş ve uzun dönemli, kapsayıcı, esnek, sonuç odaklı, hesap verebilirliği olan Performans Esaslı Bütçe yapılanması ülkemizde de olduğu gibi pek çok ülke tarafından kabul görmüştür.

Türkiye'de stratejik planlamaya dayalı Performans Esaslı Bütçe (PEB) sistemine ilişkin aşamalar; stratejik plan (hazırlık, stratejik analiz, misyon, vizyon, amaç hedefler, maliyetlendirme, izleme ve değerlendirme), performans planlama öncelikli amaç ve hedefler, performans hedef ve göstergeleri, faaliyetler, faaliyet-proje maliyetlendirme, kaynak ihtiyacı, performans programı), performans esaslı bütçe uygulama (performans bütçe, harcama birimleri, kaynak tahsisi, izleme ve değerlendirme), performans ölçme ve değerlendirme (izleme ve değerlendirme, faaliyet raporu, iç ve dış denetim, performans geliştirme ve geri bildirim), şeklindedir. Bu bir döngü halinde yıllık olarak sürmektedir (Bal, 2015, s.32). İfadeden de anlaşılacağı üzere oluşturulan stratejik plan, yıllık performans programı ve performansın izlendiği faaliyet raporları tam bir denetim, izleme ve kontrol imkanı sağlamaktadır.

5018 sayılı kanunun kapsamında kamu kurumların bütçeleri şekillenmektedir. Orta ve uzun vadeli yapılan stratejik planlamalar doğrultusunda elde edilen bütçeler, yıllık uygulamalar ve ilgili stratejik planlara göre bütçenin harcandığını gösteren ve izlenmesini sağlayan faaliyet ve performans raporları ile yürütülmesi sağlanmaktadır (Erüz, 2005, s.65).

Türkiye'de geçerli olan yaklaşım kamu üniversitelerinin devlet tarafından hazineden ayrılan bütçe ile desteklenmesi, kendi öz gelirleri, bağış, harç ücretleri ve yardımlar ile kendilerine ek kaynak oluşturmaları şeklindedir. Bu bütçeler için kurumların stratejik eylem planları önem teşkil etmekte, kurumlar yıllık veya beş yıllık uzun soluklu planlamaları ile ödeneklerini almaktadır. Performans Esaslı Bütçe yapısı tüm kamu kurumlarında olduğu gibi yükseköğretim kurumlarında da bütçe yönetimi için kullanılan sistemdir.

Son yıllarda Türkiye'de köklü üniversitelerin birim ve personel sayısı itibariyle büyük bütçeleri aldığı görülmekte, daha küçük ve yeni açılan yükseköğretim kurumlarının bu kaynaklardan çok küçük oranda faydalandığı görülmektedir. Ülkemizde hızla artan üniversite sayısı ve yükseköğretimdeki talep artışı özellikle yeni açılan üniversiteler ile on, on beş veya daha eski ve köklü üniversiteler arasında kaynak dağılımında sorgulanması gereken durumlar oluşturmuştur (SBB, 2021). Yeni açılan üniversiteler yeni bina ve kadrolaşma ve yükseköğretim talebine daha fazla destek olma gayretinde iken, kökleri daha eskiye giden öğrenci sayısı elli altmış binlere ulaşmış veya aşmış üniversiteler ise var olan fakülte ve enstitülerini daha iyi hale getirmek için kaynakları kullanma gayretine gitmiştir. Bu durum yükseköğretim kurumlarının gerek hazineden ayrılan gerekse kendi öz kaynakları ve harç, bağış, yardımlar ile elde ettikleri kaynakların daha etkin yönetimini zorunlu kılmıştır. Tüm bu gerçeklik içinde tüm kamu kurumlarında olduğu gibi yükseköğretim kurumlarında etkin kaynak yönetimi ve verimlilik, bu kurumlar faaliyetlerini sürdürdükleri sürece tartışılmaya ve sorgulanmaya devam edeceği bir gerçektir. Bu gerçeklik içinde ve günün dinamikleri ile yükseköğretim kurumlarının en ideal sistemi kendi iç dinamiklerini gözeterek, kurgulamaları gerekmektedir.

\subsection{Yükseköğretim Kurumları İçin Malzeme Tedarik Sistemi}

Yükseköğretim kurumlarında insan ve malzeme gibi kaynakların en uygun şekilde (etkin, ekonomik ve verimli) değerlendirilmesi için gerekli çalışmaları bağlı bulunulan mevzuat ve kanunlar doğrultusunda İdari Mali İşler Daire Başkanlığı tarafından gerçekleştirilmektedir (Ege iMiD, 2021; iTÜ iMiD, 2021; ODTÜ iMiD, 2021). Yükseköğretim kurumlarında merkez bütçeden birimlere (fakülte, meslek yüksekokul, yüksekokul, merkezler, rektörlük birimleri, enstitüler gibi) bir önceki yıllık talep ve faaliyet gerçekleştirim maliyetleri referans alınarak ve talepleri dikkat edilerek, üniversite merkez bütçesinden kaynak ayrılmaktadır. Bu bütçe planlaması strateji daire başkanlığı altında gerçekleştirilen stratejik plan doğrultusunda gerçekleşmektedir. Planların yıllık gerçekleşimini sağlayan performans raporu ve denetimi sağlayan faaliyet raporlarıdır. Yükseköğretim kurumları kurumun harcama kalemlerinin kanun ve mevzuata uygun olarak harcanmasından birinci derecede sorumlu idari birimidir. Her ne kadar İdari Mali İşler Daire Başkanlığı'nın görev tanımları sabit olsa da farklı kurumlarda farklı organizasyon 
şemalarına sahip oldukları görülmüştür (Bakınız; ODTÜ IMID, ITÜ IMID, EGE IMID, DEÜ IMID). Örneğin Orta Doğu Teknik Üniversitesinde İdari Mali İşler Daire Başkanlığı altında Kalite Koordinatörlüğü yapılanmış, ayrıca satın alma işlemleri için dış satınalma ve iç satınalma müdürlükleri kurulmuştur (ODTÜ iMID, 2021). Dokuz Eylül Üniversitesinde ve İstanbul Teknik Üniversitesi satınalma şube müdürlüğü altında satın alma işlemleri sürdürülmektedir (iTÜ IMID, 2021; DEÜ IMID, 2021). Ege Üniversitesinde satınalma şube müdürlükleri ihale ve satın alma şeklinde ifade edilmektedir. Tüm kurumlarda İdari Mali İşler Daire Başkanlığı ilgili üniversitenin genel sekreter yardımcılığı makamına bağııdır.

Görüldüğü üzere yükseköğretim kurumlarında İdari Mali Iş̧ler Başkanlıkları tüm kurumlar için standart bir organizasyon yapısına sahip olmasa da tüm yükseköğretim kurumlarında insan ve malzeme kaynakların etkin kullanımından birinci dereceden sorumlu idari birimdir. Yukarıda da ifade edildiği gibi yükseköğretim kurumları tüm diğer kamu kurumları gibi performans esaslı bütçe sistemi ile faaliyetlerini sürdürmektedir. Performans esaslı bütçe yapısında performans bilgisi esastır. Performans ölçüsünün oluşturulması, hedef ve göstergelerin belirlenmesi kurum yetkililerinin inisiyatifinde kurum öngörülerine dönük gerçekleştirilmektedir. Sübjektif niteliği içinde barındırması bu göstergeler için eleştiriye açık önemli bir özelliği olduğu ifade edilebilir. İdari Mali Işler Daire Başkanlığı altında etkin bütçe yönetimi ve planlamanın sağlanabilmesi için malzeme veya insan kaynaklarının yönetimine, planlanmasına, verimlilik ve etkinlik arayışına dönük çalışmaların gerçekleştirilmesi, hem performans programında kurumun gerçekçi ve kurum ihtiyaçlarına yönelik hedeflere yönelmesine, hem kurum gereksinimlerinin giderilmesine, ortaya konulan performansın kurum içinde sinerji oluşturmasına fayda sağlayacaktır. Bunu sağlayabilmek için de kurum geneli malzemelerin talep sürecinden, satın alınmasına kadar yönetilebilmesi, ardından malzemenin bir planla-uygulakontrol et ve önlem al döngüsü içinde kurum faaliyetlerinde uygun ve doğru şekilde, ihtiyaçlara dönük kullanımı, bakımı ve yaşam ömrü dolduğunda ise uygun bir şekilde geri dönüştürme işlemleri için ilgili adımların atılması gerekmektedir. Bu ihtiyaç veya ihtiyaçların bütününe dönük gerçekleştirilebilecek bir uygulama, bir kayıt sistemi, elde edilen kayıtların yönetimine ve raporlanmasına, yönetici kararlarında kullanılması, kurumsal kaynak yönetimini iyileştirebilir, kurum yöneticileri için ve denetim unsurları için bir için referans kaynak olabilecektir.

Yükseköğretim kurumlarında denetim unsuru, iç denetçiler ve Sayıştay tarafında çeşitli dönemlerde gönderilen denetçiler tarafından gerçekleştirilmektedir. Performans değerlendirilmesi ise kurum içi değerlendirme ve kurum içi değerlendirme olarak şekillenmektedir. İdare bütçesi farklı harcama birimlerine (Enstitü, fakülte, meslek yüksekokulu, yüksekokul, merkez gibi.) faaliyet ve harcama gerçekleştirim raporlarına ve malumatlarına göre dağıtılmakta, gene bu birimlerden idare faaliyet raporu çerçevesinde harcama kalemleri değerlendirilebilmektedir (Maliye Bakanlığı, 2004, s.13).

Geliştirilen bu çalışma bahsi geçen tüm bu ihtiyaçların farkına varılarak gerçekleştirilmiştir. Yükseköğretim kurumları için bir farkındalık oluşturması amacıyla, endüstri 4.0 çağında, iş zekası gibi güncel bir teknoloji ve kurumsal malzeme tedarik süreçlerinin yönetimine hizmetini ve kaydını sağlayan bilgi sisteminin geliştirilmesi ile gerçekleştirilmiştir. Olası kazanımları demo veriler ve olası senaryolar ile tartışmaya açılmış, gerek İdari Mali işler Daire başkanlıkları web sitelerinden, görev ve hizmet tanımları, misyonları ve organizasyon yapıları da analiz edilip değerlendirilerek, kurumsal bütçe dağılımındaki etkinliği ve kurumsal kaynak yönetiminde yeri tartışmaya açmaktadır.

\section{YÜKSEKÖĞRETIM KURUMLARI VE IŞ ZEKÂSI TEKNOLOJISI}

Bilgi ve iletişim teknolojilerindeki ilerleme, her sektörde olduğu gibi eğitim sektöründe de son teknoloji araçlarının kullanılmasını zorunlu kılmaktadır. Bu durum hem sektör içindeki rekabetten hem de sektörün bir paydaşı olmuş yöneticilerin işlerini iyi yapma ve yürüttükleri faaliyetleri bilgiye dayanan etkin kararlar alarak sürdürme arzusundan kaynaklandığı ifade edilebilir. Bu durum eğitim sistemi içinde sadece rekabet avantajı sağlayan bir unsur değildir. Eğitimin öğrenci, öğretmen, bütçe, aktiviteler, materyal gibi pek çok aşamasına hakim, süreçleri kontrol altına almış yöneticiler, faaliyetlerinin verimli ve sürdürülebilir olmasını sağlayacakları gibi, sunulan hizmetin bilgi ve taleplerin bütünleşmesi ile olmasını sağlayacaklardır. Zulkefli ve diğerleri (2015), üniversiteler, iç ve dış kaynaklardan toplanan ve dağıtılan artan miktarda veri nedeniyle, mevcut veri ve bilgilerin daha iyi kullanılması için sürekli olarak yeni teknik ve yönetsel yaklaşımlar arandığını, ortaya çıkan bilgi ve iletişim teknolojilerindeki ilerlemeler, üniversitelerin daha önce mümkün olmayabilecek verileri toplamak için yenilikçi araçlar geliştirmesini sağladığını ifade etmiştir. İ̧̧ zekası teknolojisi bu noktada pek çok sistemden beslenen ve günümüzde operasyonel, taktik ve stratejik düzeyde farklı karar seviyelerinde kullanılabilecek bir dijital araç olarak karşımıza çıkmaktadır.

Damar ve diğerleri (2018, s.197), iş zekası teknolojisi için veri madenciliği ve diğer istatistiksel yöntemler ile birlikte kullanabilen, ihtiyaca dönük kolay, hızlı ve etkin bir şekilde 
kurgulanabilen, amaç ve hedeflere dönük raporlar sunan bir teknoloji olarak ifade etmişlerdir. Duan ve Xu (2012, s.679) iş zekası teknolojisini kurumsal faaliyetler sonucunda elde edilen ham verilerin stratejik, taktik veya operasyonel karar verme amaçları için yararlı bilgiye dönüştürme süreci olarak ifade etmişlerdir. Zeng vd., (2012,s.297), iş zekasını, doğru bilgiyi doğru zamanda doğru formatta toplama işlemi olarak belirtmiştir. Üretilen sonucun işletme karar süreçlerine doğrudan bir etkisi olduğunu belirtmiştir.

Mudzana ve Maharaj (2015, s.2) iş zekası teknolojisini, estetik açıdan zengin ve amaca yönelik raporlar üreten bir teknoloji ve karar vermeyi geliştirmek için kullanılan uygulamalar olarak tanımlamaktadır. Wowczko (2013, s.1107) iş yerinde insanların daha iyi kararlar almasına yardımcı olan bir dizi teknoloji ve çözüm olduğunu belirtmiş, iş zekası teknolojisinin karar vermedeki rolüne vurgu yapmıştır. Hartley ve Seymour $(2010$, s.116) iş zekasını; veri birleştirme, analiz ve raporlama yetenekleri sunarak, kullanıcıların bir kuruluşun verilerinden en iyi şekilde yararlanmasına yardımcı olan bir bilgi ve iletişim teknolojisi aracı olarak tanımlamaktadır. İş zekası raporlarının en önemli özelliği belirlenen amaç ve ihtiyaçlara dönük ve bu ihtiyacı giderecek ilgili verilere göre hazırlanmasıdır. Bu nedenle iş zekası, doğru bilginin doğru zamanda doğru formatta toplanmasını gerektirir.

Organizasyonlar, bu teknolojilerin yardımıyla değer ve rekabet avantajı yaratmak ve sürdürmek için geliştirilen bilgi ve becerileri kullanabilirler (Mitchell ve Boyle, 2010, s.67). Raporlama sistemlerinden elde edilen bulgular, işletmelerdeki operasyonel, taktik ve stratejik karar süreçlerinde etkilidir. (Zeng vd., 2012, s.297). Kuruluşlar iş zekası teknolojisini çeşitli amaçlar için kullanabilir ve kullanıcı sayısı ve kullanım alanları karar verme ihtiyaçlarına göre değişebilir (Ateş, 2008: 45). Bu bağlamda Ahmed ve diğerleri (2011) ilgili uygulama türlerini stratejik, taktik ve operasyonel iş zekası olarak sınıflandırmış ve Ahmad (2015) bir iş zekası modelinin genel bir çerçevesini önermiştir.

İs zekasının temel amacı, verilere etkileşimli erişim (genel olarak gerçek zamanlı), veri manipülasyonuna izin vermek ve işletme yöneticilerinin ve analistlerin ilgili analizleri yapmalarını sağlamaktır. Verilerin bilgiye, kararlara ve nihayetinde eyleme dönüştürülmesi, iş zekası sisteminin temelidir. Başarılı bir iş zekası sürecinin merkezinde, yüksek mimari yeteneklere sahip iyi tasarlanmış bir veri ambarı yer almaktadır. Son kullanıcılar, iş zekası kapsamında çeşitli araç ve teknikleri kullanarak bir veri ambarında ve iş analitiği kapsamında sağlanan platformlarda veriyle çalışabilirler (Eckerson, 2003).
Literatür incelendiğinde yükseköğretim kurumlarında iş zekasının uygulanmasına dönük pek çok çalışmaya rastlanmaktadır. Gerçekleştirilen çalışmalar yükseköğretim kurumlarında etkin ve sürdürülebilir bir bilgi sistemi için iş zekasının önemini (Guster ve Brown, 2012; Scholtz vd., 2018), büyük veri ve yükseköğretim kurumlarında büyük veri ile baş edebilmek için etkin bir teknoloji olarak iş zekası teknolojisini (Ong, 2016; Gupta vd., 2015), yükseköğrenim kurumları için veri analitiği için iş zekası teknolojisinin kullanımı (Drake ve Walz, 2018), yükseköğretim kurumlarında kaynak yönetimine dair çözüm olarak iş zekası teknolojisinin kullanımını (Kleesuwan, 2010; Calitz vd., 2018) tartışan pek çok farklı başlıkta çalışmalardır. Bilgi üreten, tüm sektörlerin nitelikli istihdam gereksinimlerini çözebilmek için personel yetiştiren yükseköğretim kurumlarında çağın gereksinimlerine uygun bir yönetim anlayışı gereksinimi şarttır. Ülkeler arasında hangi ülkeler yükseköğretim kurumlarında işledikleri insan kaynağını en etkin kullanıyorsa uzun vadede teknolojide, ekonomik gelişmede ve toplumsal refahta ön plana çıkmaktadır. Bu nedenle içinde bulunduğumuz çağda özelikle Türkiye gibi kıt kaynaklara sahip ülkeler için var olan kaynakların en etkin şekilde yönetilmesi elzemdir. Kurumsal ihtiyaçların yönetilmesi ve bunların denetlenmesi, kontrol edilmesi ve elde edilen veriler üzerinde değerlendirmede bulunulabilmesi, bunun yönetici ihtiyaçlarına yönelik etkin bir şekilde görselleştirilmesi yükseköğretim kurumları için de gereksinim duyulan bir unsurdur.

Yükseköğretim kurumlarının performansa dayalı bütçe yönetimi içinde pek çok farklı birim üzerinden gelecek malzeme taleplerine karar verilmesi ve bu taleplerin yoğunlaştığı noktalarda iyileştirmelere gidilebilmesi etkin malzeme yönetimini, etkin tedarik sürecini ve özetle kaynak yönetimini sağlayacaktır. Yukarıda ifade edilen tüm tanımlar ve yükseköğretim kurumlarında kullanım alanları dikkate alındığında iş zekası teknolojisi bu noktada uygun bir teknolojidir.

\section{YÖNTEM}

Çalışmada yükseköğretim kurumlarında kaynak yönetimi için önemli bir unsur olan ve kurumsal bütçe ve giderler içinde önemli bir yere sahip yıllık tedarik edilen malzemelerin (gıda, servis hizmetleri, temizlik malzemeleri, kırtasiye gibi.) etkin satın alınması ve sonraki etapta tedarik edilen ürünler üzerine iyileştirme çalışması yapılabilmesi için bir bilgi sistemi modellenmiş ve demo veriler ile çalıştırılmıştır.

Gerçekleştirilen sistemin geliştirilmesi sürecinde:

- Yükseköğretim kurumlarının bütçe yönetimi mevzuat ve kanunlar yönünden incelenmiştir. 
- Yükseköğretim kurumlarına Türkiye'nin genel bütçesi içinde ayrılan ödenek ve kurumların özgelirler değerlendirilmiştir.

- Literatürde gerçekleştirilmiş bütçe, bütçe yönetimi, iş zekası teknolojisi ve yükseköğretim kurumları için uygulama alanları, yükseköğretim finansmanı, stratejik plan, yükseköğretim kurumlarında idari mali işler ve strateji geliştirme daire başkanlıkları gibi pek çok farklı başıkta literatür taraması yapılmıştır. Bu sayede çalışmanın doğru amaca hizmet etmesi, probleme en doğru şekilde odaklanılması ve yükseköğretim kurumları ihtiyaçlarına dönük etkin bir çalışma modelini ortaya koyabilmesi amaç edinilmiştir.

- Kurumların ilgili birimlerinin web siteleri üzerinden değerlendirmelere gidilmiş, kurumsal kaynak yönetiminin etkinleştirilmesi için olası tüm kaynaklardan geri bildirimler derlenmiştir.

- Yükseköğretim kurumlarında kaynakların yönetiminden birinci derecede sorumlu olan birimi İdari Mali İşler Daire Başkanlığının görev tanımları ve sorumlulukları, pek çok yükseköğretim kurumunun internet sayfasındaki veriler de analiz edilerek değerlendirilmeye gidilmiştir.

- Yükseköğretim kurumlarının malzeme tedarikinden ve satın alma sürecinin yükseköğretim kurumunda nasıl şekillendiği üzerinde bir analiz gerçekleştirilmiştir.

- Kurum ihtiyaçlarının neler olabileceği üzerinde değerlendirmede bulunulmuş, bilgi sistemi inşaası ve modellenmesi için intiyaç analizi gerçekleştirilmiş, gerekli sistemin modellenmesi ve kodlanmasına geçilmiştir.

- Olası veri akışlarına dönük, değişik seviyelerden olası yönetici intiyaçları da dikkate alınarak Microsoft Power BI iş zekası teknolojisi ile bir raporlama ve veri analiz uygulaması geliştirilmiştir.

Geliştirilen uygulamada kullanılan teknolojiler Oracle veritabanı, PHP Programlama Dili, Microsoft Power BI iş zekası teknolojisidir. Raporlama ve görüşmeler sürecinde Microsoft Office Word ve Microsoft Office Excel programlarından da faydalanılmıştır. Ayrıca bir web uygulaması olduğu için HTML, CSS ve Javascript dilleri de ayrıca geliştirme aracı olarak kullanılmıştır.

\section{BULGULAR ve TARTIŞMA}

Çalışmada, yöntem bölümünde de ifade ettiğimiz adımlarda elde edilen bulgular ve uygulama deneyimi ve edinilen tecrübe paylaşılacaktır. Öncelikle ilk söylenmesi gereken nokta, literatür bölümünde de paylaşıldığı üzere kamu kurumlarında performansa dayalı bütçe yönetimi içinde geliştirilen bu ve bunun gibi uygulamaların gerek kurumsal kaynak yönetimine gerekse etkin ve verimli kurumsal yönetişime katkı sunacağı ifade edilebilir. Farklı başlıklar altında yukarıda literatür bölümünde de ortaya konulduğu gibi, içinde bulunduğumuz endüstrü 4.0 çağında, bilginin ve bilgi sistemlerinin her geçen gün hayatımızın her noktasına girdiği bu dönemde, yükseköğretim kurumlarında daha etkin yönetim için çağın nimetleri olan teknolojilerden üniversitelerin daha fazla kullanması gerekmektedir. Aşağıda sırasıyla iş süreçlerinden elde edilen deneyim ve kurum web sayfalarından elde edilen bilgiler ışığında edinilen bilgiler paylaşılmakta, ardından geliştirilen uygulamamı için entity relationship diyagram dediğimiz varlık-bağıntı modeli sunulmakta, geliştirilen uygulamanın ekran görüntüleri ve belirlenen kullanıcı rollerine göre fonksiyonları ortaya konulmaktadır.

\subsection{Sorumlu Birimler ve Saha Değerlendirmesi}

Geliştirilen uygulama öncesinde yükseköğretim kurumlarında kaynakların yönetiminde hangi birim veya birimlerin etkin bir şekilde görev aldığı üzerine mevzuat, kanun ve yönetmelikler yanında, kurum organizasyon yapıları ve internet sayfaları üzerinden değerlendirilmeye gidilmiştir. Elde edilen ilk bulgularımız insan ve mali kaynakların yönetiminden İdari Mali İşler Daire Başkanlığının görev aldığı görülmektedir. Her ne kadar insan kaynakları dendiğinde ilk akla gelen birim yükseköğretim kurumlarında personel daire başkanlıkları olsa da özellikle gerçekleştirilen internet sayfası analizinde sözleşmeli personellerin istihdamı konusunda sorumluluk aldıkları görülmektedir. Bu durumun kurumun mali kaynaklar konusunda sorumlu olmasının getirdiği bir fonksiyon olduğu ifade edilebilir. Alınan temizlik veya güvenlik hizmetlerinin, farklı bir kurum tarafından üniversitelere satışı, ihale yoluyla gerçekleşmektedir. İlgili birim bu ihale sürecinden sorumludur. Mali noktada ihale ve servis hizmetinin satın alınması sürecinde yerine getirilen sorumluluğunun personel yönetimi veya destek hizmetleri personelleri üzerinde bir kaynak yönetimi fonksiyonuna dönüştürmüştür. İçinde bulunan bu durum üniversitelerde Personel Daire Başkanlıklarının sorgulanan niteliklerine (Damar vd., 2021, s.40-41) bir başka sorgu atmaktadır. Gökşen ve diğerleri (2015), yükseköğretim kurumlarında bu şekilde destek hizmeti gibi görev alan sözleşmeli personellerin aslında kurumun iş gücü kaynağında rakamsal olarak ve sağladığı hizmetler açısından önemli bir yer edindiğini, kuruma da önemli bir maliyetinin olduğunu ifade etmiştir. Ayrıca kurumlara işgücü istihdam etmek stratejik bir karar noktası olduğunu ve işgücü verimliliğinin ölçülmesi ve yönetilmesi gereken önemli bir performans ölçütü 
olduğunu belirtmişlerdir. Bu fonksiyonlar ise İdari Mali Iş̧ler Daire Başkanlığı tarafından mı yoksa Personel Daire Başkanlıkları tarafından gerçekleştirilecektir?

Damar ve diğerleri (2021, s.40-41), modern anlamda insan kaynakları yönetiminin yükseköğretim kurumlarında gerçekleşmediğini, bu konuda problemleri olduğunu belirtmişlerdir. Personel Daire başkanlıklarının günümüz dinamikleri ile görev tanımları ve sorumluluk alanlarının tüm kurumlarda insan kaynaklarını misyonu ile revize edilmesinde fayda görülmektedir. Genel olarak personel daire başkanlığı birimi, özel üniversitelerde insan kaynakları adıyla faaliyet göstermektedir. Özellikle kamu kurumlarındaki yetkililer, kurumlarının personel daire başkanlıklarını yeterli görmektedir.

Kamu üniversitelerinde mali bütçenin etkin kullanımı ve yönetimi konusunda Strateji Geliştirme Daire Başkanlıkları ve İdari Mali İşler Daire Başkanlıkları bu birimlerin sorumlu olduğu üst yönetim ile birlikte, öncelikli sorumlu idari birimlerdir. Kamu kurumlarında bütçe yönetimine ilişkin sorgulanan sorular şu şekildedir;

- Üniversitelerde bütçe planlaması neye göre nasıl yapılmakta ve nasıl takip edilmektedir?

- Birimler bütçeleri neye göre dağıtılmakta ve nasıl kontrol edilmektedir?

- Kurum dışından kurum bütçesinin denetimine yönelik ne tür sistemler mevcuttur? illgili sistemlerin kurumu bağlayıcı yönleri nelerdir?

- Kurum kaynakları için stratejik plan, performans programı ve faaliyet raporu nasıl hazırlanmaktadır?

- Kurum içi performansa dayalı bütçeleme için performans ölçütlerini ortaya koyan bir yazılım mevcut mudur?

- Öngörülmeyen bütçe kalemleri için nasıl bir yol izlenmektedir? Ek bütçe kalemleri için nasıl bir yol izlenmektedir?

- Sahip olunan insan ve maddi kaynakların denetiminde kurum içi ve kurum dışı denetim nasıl gerçekleştirilmektedir?

- Malzeme tedariki için olası bir kayıt veya bilgi sisteminden beklentiniz, denetim, koordinasyon, sürdürülebilirlik ve yönetim fonksiyonları ile değerlendirildiğinde nelerdir?

Orta Doğu Teknik Üniversitesinin 2020 yılı ödenekleri üzerinde bir değerlendirme yapıldığında; kuruma toplamda 575.977.000 TL ödenek tahsis edilmiş ve bu ödeneğin 512.003.000TL'si hazine yardımı ve 63.974.000
TL ise öz gelirden karşılanmıştır (ODTÜ Mali Tablolar, 2021). Kurum kaynaklarının yaklaşık \%12'sini kendi oluşturduğu öz gelirden elde ettiği, bu oranın Türkiye'deki Yüksek Öğretim Kurumları içinde yüksek bir oran olduğu ayrıca görülebilir (SBB, 2021). İstanbul Teknik Üniversitesi (iTÜ Bütçe Giderleri, 2021) ve Orta Doğu Teknik Üniversitesi (ODTÜ Mali Tablolar, 2021) gibi kurumların mali bütçe yapılanmaları değerlendirildiğinde, kurumlarının merkezi bütçeden elde ettiği bütçenin yaklaşı \%80-85'inin zorunlu harcamalara gittiğini görülebilmektedir. Örneğin bir kurumun elinde bulunan 100 liranın 85 lirasının aslında yaşamsal faaliyetleri olan eğitim, öğretim ve araştırma faaliyetlerinin sürmesi için bina, enerji, maaş, kira vb. harcamalara gittiğini ifade etmişlerdir. Bu harcamaların, personel giderleri, elektrik, doğalgaz, su ve benzeri enerji ve tüketim giderleri yanında kira ve zorunlu lisans anlaşmaları (kullanılan ofis yazılımları, işletim sistemi yazılımları, özel araştırmalarda kullanılan paket programlar, özellikle kütüphane süreçlerinde zorunlu olarak erişim sözleşmeleri, çeşitli veri tabanların bağlanma ve kaynak erişim yetkileri gibi) giderlerinin olduğu ayrıca belirtilmiştir. Aslında yükseköğretim kurumlarının elinde bulunan \%20-15'lik bir bütçe kaleminde etkinlik alanı olduğunu ve performans veya verimlilik unsurlarının bu \%20-15'lik dilim için gerçekleşebileceğini, kurum inisiyatifinde olabileceğini ifade edilmiştir. Elde edilen bulgular ışığında özellikle tüm kamu kurumları için zorunlu olan \% 80-85 giderlerinin Türkiye'deki tüm devlet üniversiteleri için geçerli harcamalar olarak da ifade edilebilir. Bu probleme bütüncül bir şekilde yaklaşılmasında fayda görülmektedir. Büyük bir oran ve büyük bir kaynak karşımızda bulunmaktadır. Bu kaynak üzerinde tüm kurumlarımızı iyileştirebilecek iyi düşünülmüş ve kurumların iyileşmesini sağlayacak projelerin Türk Yükseköğretim Sistemi içinde önemli kazanımlara sebep olacağı ifade edilebilir. Belki de TÜBITAK tarafından etkin insan ve maddi kaynakların yükseköğretim kurumları için yönetimi veya kamu kaynaklarının etkin yönetimi proje çağrı başlıkları ile fon sağlaması yararlı olabilecektir.

Ayrıca elde edilen bir diğer kritik bulgu, T.C. Hazine ve Maliye Bakanlığı tarafından tüm kamu kurumlarında olduğu gibi devlet üniversitelerine de zorunlu olarak çeşitli dönemlerde çeşitli verilerin belirlenen kurum yetkililerince Kamu Harcama ve Muhasebe Bilişim Sistemi (KBS) üzerinden girildiği verisidir. Bu tür sistemlerin olması kurum yetkilileri tarafından ilgi ile karşılanmakta ve kritik önemde görülmektedir.

KBS yani Kamu Harcama ve Muhasebe Bilişim Sistemi projesi ile "harcama ve muhasebe birimlerinin mali işlemlerini bir otomasyon sistemi içinde toplamak suretiyle harcamayı tahakkuk ettiren harcama birimleri ile ödemeyi 
gerçekleştiren muhasebe birimleri arasında güvenli, hızlı ve elektronik ortamda bilgi akışının sağlanmasını hedefleyen" bir projedir ve "KBS alt sistemleri olarak geliştirilen uygulamalar, yaklaşık 60.000 harcama biriminde değişik rollerde yaklaşık 200.000 kişi tarafından kullanılmaktadır." (KBS, 2021). Hazine ve Maliye Bakanlığı Muhasebat Genel Müdürlügü internet sayfasında KBS alt sistemleri; Kamu Personel Harcamaları Yönetim Sistemi (KPHYS), Harcama Yönetim Sistemi (HYS 2018), Taşınır Kayıt ve Yönetim Sistemi (TKYS), Genel Yönetim Mali İstatistik Uygulaması (GYMiS), Kamu Elektronik Ödeme Sistemi (KEÖS), KBS Kullanıcı Raporları (Bütçe, Personel vb.), Sendika Uygulaması, İhtiyaç Fazlası Taşınır Uygulaması, uygulama destekleri için çağrı merkezi, Kamu Elektronik Bordro Sistemi (e-Bordro), Kamu Taşıtları Yönetim Bilgi Sistemi (TBS), şeklinde sıralanmıştır (KBS, 2021).

Kurumlar için sunulan bilgi sistemlerinin önemi büyük olmak ile birlikte, ilgili uygulamaların merkezi sistemin ihtiyaçlarına yönelik kurgulandığı, merkezi otoritenin izleme ve kontrol amaçlarına yönelik olduğuna dönük bir intiba uyanmıştır. Elde edilen kritik bulgulardan birisi kamu kaynaklarının etkin kullanımına dönük servis edilen bu uygulamaların birlikte konuşması konusunda problemlerin olduğu veya etkin kullanılamadığıdır. Ayrıca kullanılan uygulamalarda üniversitelerin etkinliğini artıracak, lokal olarak çalışan, sıfırdan bir satın almayı (iki yüz üzerindeki üniversite için iki yüzün üzerinde satın alma işlemi yapar. Yazılımların nitelik ve sürdürülebilirliği, etkinlikleri de uzun vadede tartışılması gereken diğer risk ve olgulardır.) gerektirmeyecek şekilde, geliştirilen bu merkezi sistem üzerinde modüler bir şekilde kurum yöneticilerine değişik seviyede kaynak yönetiminde karar verme süreçleri için destek olacak ek uygulamaların geliştirilmesinin çok gerekli olduğunu belirtmişlerdir.

Geliştirilecek bu yönde bir uygulamanın şeffaf yönetim ilkesi ile uyumlu olabileceği, kayıt altına alınan harcama bilgilerinin, iç ve dış denetim organları için önemli referans veri sağlayacağı da ayrıca ifade edilebilir. Tüm kamu kaynakları için referans bir veri ambarı oluşturabilecektir. Bu şekilde bir kaynak zorunlu harcamalar veya ödeneklerden etkin faydalanılması adına, merkezi birimlerde yer ala kural koyucular, planlamacilar, performans yönünden iyileştirme arayışı içinde olan araştırmacı ve uzmanlar için önemli bir veri kaynağı oluşturacağı da ortadadır.

Ayrıca Damar ve Karaman (2021, s.206)'ın çalışmalarında da belirttiği gibi, kurumların faaliyetlerini daha şeffaf ve verimli sürdürebilmeleri, hesap verilebilmeleri ve vatandaşın bilgilenmesi için önemli görülmekte, bu noktada kamu kurumlarının açık veri olarak faaliyetleri konusunda kamuya veri sunmasında fayda görülmektedir.
Kamu kaynaklarının etkin kullanımı, olası usulsüzlüklerin engellenmesi, kaynakların daha etkin kullanımına dönük akademik çalışmaların yapılabilmesi adına da bu tür girişimler önemli görülmektedir. Bu noktada bilbiyometrik veri tabanlarında olduğu gibi farklı analizlere imkan sağlayacak dosya formatları ile veriler araştırmacılara sağlanabilir. Özellikle sosyal bilimler alanında oluşan veri sıkıntısı ve gerçek problemlere dönük üretilecek çözüm çalışmalarına da katkı sunacağı, kamu yönetim fonksiyonlarını daha şeffaf, hesap verebilir şekilde tartışmasına imkan vereceği düşünülmektedir. Gerçekleştirilecek bu tür çalışmalarda yetkililerin, Kişisel Verilerin Kullanım Kanunu, kamu bilgisinin gizliliği ve diğer mevzuat ve yönergelere uygun maksimum faydalı bilginin paylaşılmasında, ülkemizde şeffaf yönetim algısının gelişmesi, açık veri konusunun daha iyi idrak edilmesi ve kamu kaynaklarının etkin kullanımı için fayda sağlayacağı düşünülmektedir.

Ege Üniversitesi İdari Mali İşler Daire Başkanlığı web sitesinde (EGE IMID, 2021) hizmetlerimiz başlığı altında; "Aylık bütçe harcamalarının kontrolünü yapar ve içinde bulunan günün mali durumunu inceler, gerektiğinde ilgili yerlere bilgi verilmesini sağlar.", hizmet kalemi yer almaktadır. Bu hizmet kaleminden de anlaşılacağı gibi İdari Mali İşler Daire Başkanlıkları elde kalan bütçenin kullanımı konusunda üst yöneticilere bilgi vermek ve bütçenin etkin kullanımı konusunda da önemli sorumluklara sahip olduğu görülmektedir. Birimlerden gelen ek bütçe taleplerini, kaynakların etkin yönetimi, ilgili birim için önemli bir sorumluluk alanı olarak ortaya çıkmaktadır. Idari Daire Başkanlıkları sayesinde birimlerin satın alma faaliyetleri koordine edilebilir ve birimlerin zorunlu harcamaları olarak ifade edebileceğimiz, enerji ve maaş gibi giderler dışında kalan kaynakların daha etkin kullanımı sağlanabilir. Yükseköğretim kurumlarının malzeme ve diğer kaynakların tedarik yönetiminde süreçlerin etkinleştirilmesinde birinci sorumlu birim olarak görülebilir.

\subsection{Geliştirilen Uygulama, Fonksiyonlar, Varlık Bağıntı Modeli ve Ekran Görüntüleri}

Elde edilen tüm bulgular ve kurumsal ihtiyaçları gözetilerek, birim aktif yönettiği kaynakların üzerinde bir tasarrufa gidilmesinin fayda sağlayacağı düşünülmüştür. Üniversitelerin ana bütçesi üzerinden fakülte, meslek yüksekokulu, enstitülere ayırdığı bütçeler ilgili birimlerin inisiyatifinde gerçekleşmektedir. Geliştirilen uygulamada komisyon ve birim harcama yetkilileri ve malzeme tedarik süreci sonrası planlama ve performansa dönük iyileştirmeleri gerçekleştiren birim olmak üzere üç farklı rol tanımlanmıştır (Şekil 1). Aşağıda Şekil 1 üzerinde tasarlanan sistem şekil üzerinde ifade edilmektedir. Ayrıca geliştirilen sistemin görünümü yanında, tasarlanan ilişkisel veri modeli 
ise Şekil 2 üzerinde ifade edilmektedir.

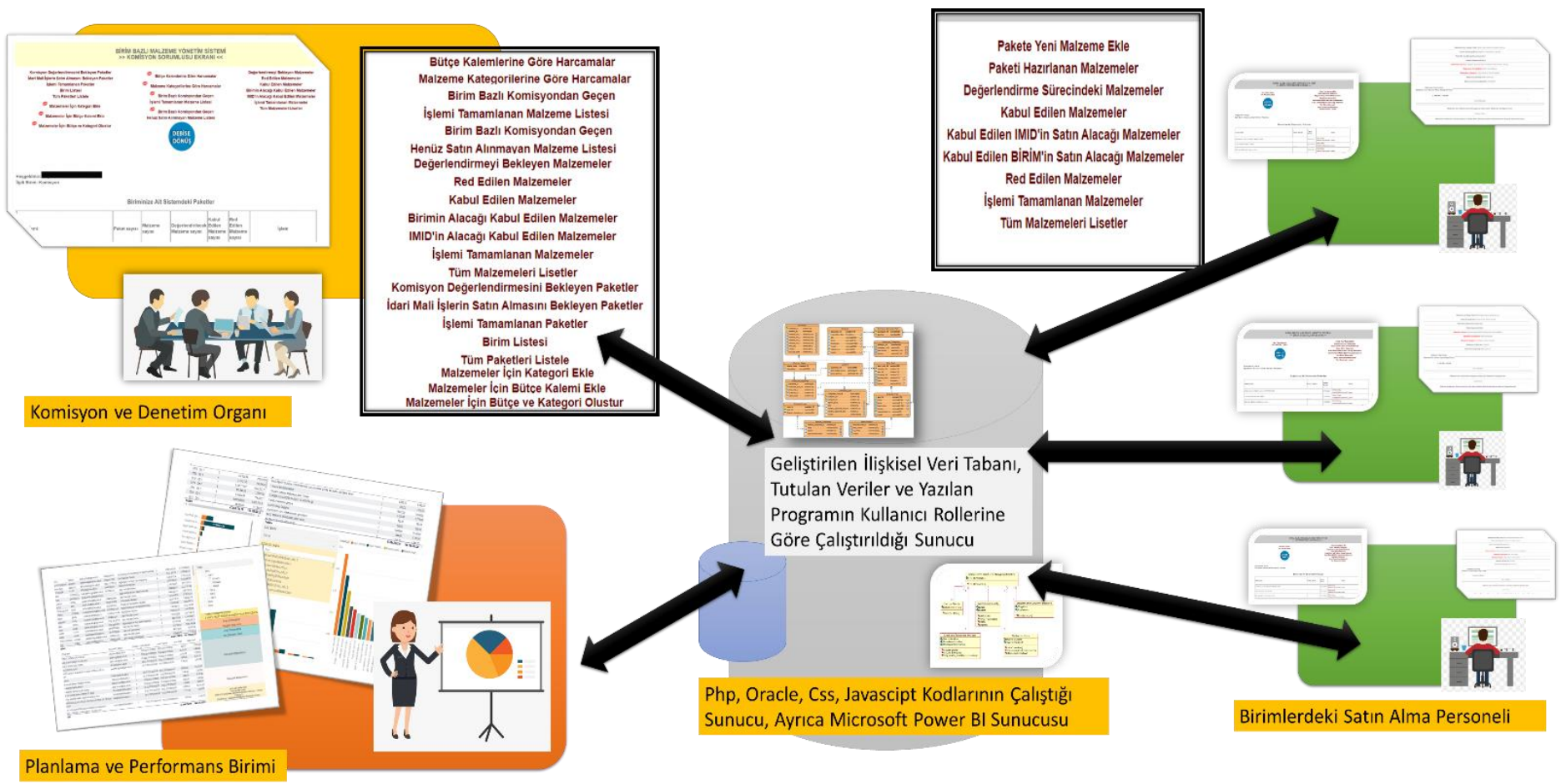

Şekil 1. Geliştirilen Uygulamanın Ana Görünümü Modeli

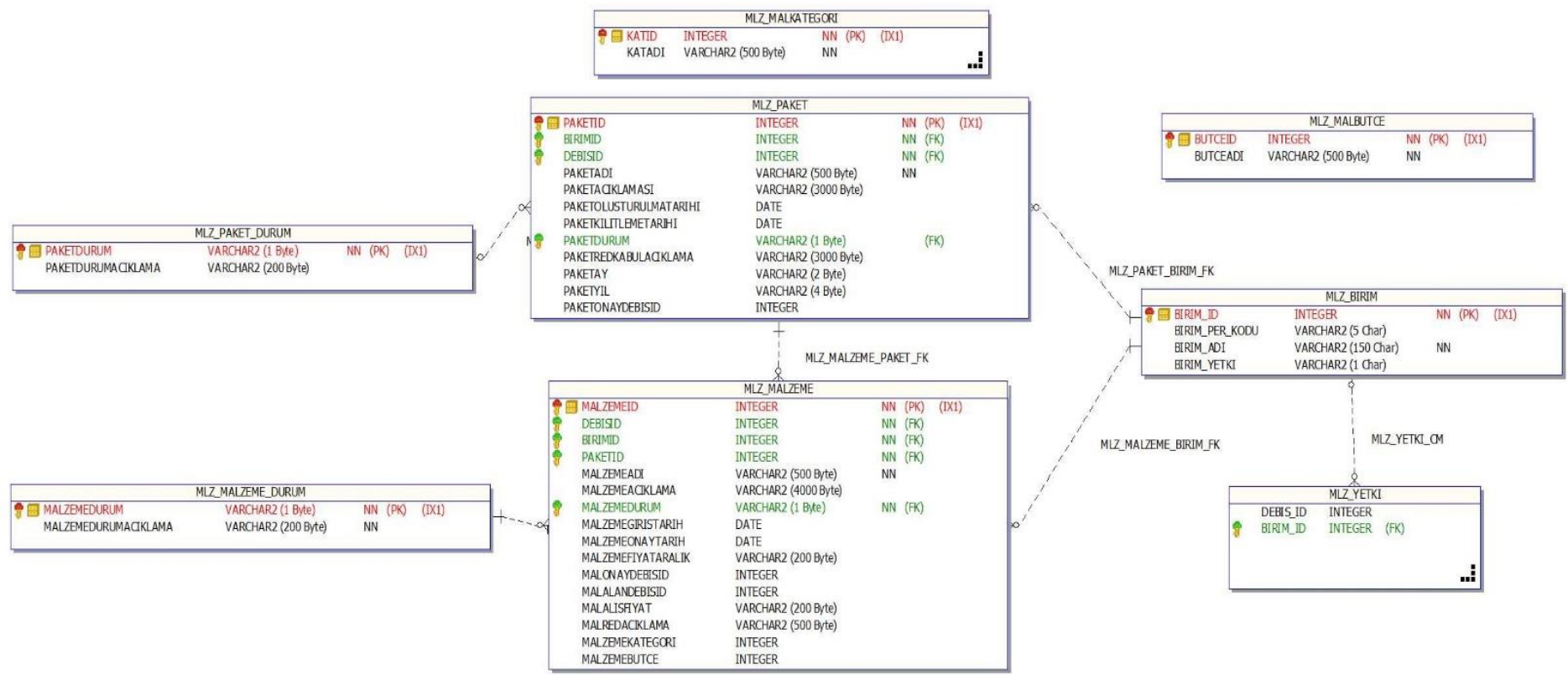

Şekil 2. Geliştirilen Uygulamanın Varlık-Bağıntı Modeli (ER Diyagramı)

Geliştirilen uygulama planlama ve performans birimi için önemli bir kaynak oluşturacağı ifade edilebilir. Çalışma malzeme yönetim ve kayıtlı veri üzerinde sorguları ön plana almaktadır. Parametrik raporlamaya imkan sağlamaktadır. Bu sayede harcama kalemlerinin kontrolü hedeflenmiştir. Geliştirilen uygulama aracılığı ile satın almacılar için bir veri giriş ekranı oluşturulduğu, komisyon tarafından talepler değerlendirildiği, pek çok raporun alınabildiği, geliştirilen iş zekası teknolojisi ile planlama ve performans biriminin daha ileri analizleri gerçekleştirilmesine imkan sağladığı görülebilir.

Geliştirilen sistem sayesinde dönemsel olarak tarih bazlı, ürün bazlı, malzeme kategorisi bazlı sorguları kullanıcılar yapabildiği gibi, daha detaylı ve görsel rapor ihtiyaçlarının planlama ve performans biriminin ihtiyacı olacağı düşüncesi ile Microsoft Power BI ile veri tabanı üzerinde bir iş zekası 
raporlama sistemi kurgulanmıştır. Bu raporlama sistemi sayesinde demo veriler aracılığı ile kişi, birim, malzeme satın alınan firmalar, malzeme, ve malzeme kategorosi bazlı raporlamalar zamansal, miktar bazlı veya harcama tutarları odaklı analizleri gerçekleştirilebilmiştir.

Satın alma süreçlerinde bir ürün tedarik edilirken farklı birimlerden teklifler alınmaktadır. Piyasada tek olan firmalar haricinde genelde üç veya daha fazla teklif alınması satın alma personeller tarafından arzulanan durumdur. Satın alma personelinin ve ihaleye giren firmaların ilişkisel veri tabanı diyagramında da görüleceği üzere pek çok referans veri alınmaktadır. Bu noktada ilk ve son teklifler, satın alma sürecine dahil olan kişi veya şirketler, ilgili tarih gibi unsurlar, satın alma sürecinin denetim ve kontrolü için kritik referans bilgiler olduğu ifade edilebilir. Malzeme bilgilerinde birim maliyet, alınan ürü adeti, toplam maliyet gibi unsurlar da farklı birimler için referans olabilecek diğer bilgilerdir. Bu veriler sayesinde, aynı ürüne farklı birimlerce ödenen yüksek rakamları engelleyebilir, toplu satın almaya gidebilir veya birimin farlı birimden alması yerine satın almacının henüz teklif almadığı, fakat kurumun farklı bir birimine daha düşük fiyat vermiş ilgili firmasından satın alması sağlanabilir.

Aynı ürünü bir birim üç $\mathrm{tl}$ öderken bir baka birim dört $\mathrm{tl}$ ödeyebilmekte bu tür durumlar da kurumsal kaynaklarda tasarrufu ve etkin bütçe yönetimini engelleyebilmektedir. Elbette aynı ürün veya hizmet için farklı birimlerin ödediği farklı ücretlerin lojistik olarak güç temin edilmesi, bölgede tek olma gibi çeşitli nedenler de olabilir. Geliştirilen bu tür uygulamalar kurumsal hafiza ve kurumsal malzeme bilgi sistemi için bir veri ambarı oluşturabilmektedir. Bu veri ambarı üzerinden ortaya çıkabilecek kümelenmeler, harcamalar üzerine belirlenen iyileştirme alanları sayesinde kurumsal kaynak yönetimi etkinleştirilebilir. Örneğin, tüm kurumlarda zorunlu olabilecek mazot gibi yakıt alımları, asansör giderleri veya klima bakım onarım hizmetleri tek bir kurum ile anlaşılarak, kurum geneli ihale edilmesi ile çözülebilir. Bu sayede hizmet verilecek kurum sayısı avantajından faydalanılarak servis hizmetinde ücret avantajına erişilebilir.

Bütçeleme, bilgiyi karara dönüştüren bir süreçtir. Harcama birimleri tarafından gönderilen veya merkezi bütçe personeli tarafından üretilen talepler sürece girilir ve kuruluşlara, projelere ve diğer alıcılara tahsisler çıkarılır. Bu kararların kalitesi, karar vericiler için mevcut verilere ve bilgiyi işlemek için kullandıkları analitik araçlara bağııdır (Schick, 2007, s.110). Geliştirilen bu tür uygulamalar yöneticilerin bütçe yönetim faaliyetleri için karar destek sağlayabileceği gibi denetim süreçleri için de referans bilgi sağlamaktadır.
Çıktıları göz önüne alan performans esaslı bütçe yapısı, sonuç esaslı yönetim, performans yönetimi gibi adlandırımalar ile kullanılabilmekte ve etkinlik, verimlilik kavramlarıyla ilişkilendirilebilmektedir (Köseoğlu, 2007, s.325). Burada temel amaç; kamu yönetimi için kıt kaynakların en mantıkı ve rasyonel şekilde değerlendirilmesine imkan vermektir (Demirel, 2015, s.156). Bu unsurlar ile geliştirilen uygulama değerlendirildiğinde, aylık, üç aylık veya bir yıllık satın alınan ürünlerin yoğunlaştığı alanların keşfi için imkan sağlamaktadır.

Ayrıca hangi ürünlerin hangi birimlerce daha fazla kullanıldığı, hangi tür ürünlerin hangi dönemlerde satın alabileceği, hangi ürünlerin toplu satın almaya daha uygun olduğu, birimler arasında aynı marka-model-türdeki ürün için ödenen farklı fiyatlar konusunda farkındalık oluşturulması sağlanabilir. Ürünlerin ilgili birimler tarafından hangi dönemlerde daha yoğun alındığını bilmek etkin bir tedarik ve stok yönetimi de sağlayabilir.

Ayrıca, birlikte temizlik, kırtasiye, baskı giderleri gibi giderler üniversitelerde tüm birimler için ortak kabul edilebilecek harcamalardır. Bu tur zaruri harcamalar merkez bir depo ve oluşturulacak dağıtım sistemi ve envanter kayıt sistemi sayesinde, toplu satın almanın getireceği maliyet avantajı sayesinde daha ucuza temin edilebilir.

Kaynakların hesap verilebilirlik, mali disiplin ve şeffaflık ilkeleri temelinde vatandaş (müşteri) odaklı anlayış çerçevesinde etkili, etkin ve verimli kullanımının amaçlandığı performans esaslı bütçe sisteminin teorisi basit fakat uygulaması zor olan bir bütçeleme sistemi olduğu görülmektedir (Bal, 2016, s.25). Geliştirilen uygulamalarının performans göstergeler yanında bu tür kaynakların etkin kullanılıp kullanılmadığı hususunda araştırmacıya önemli bilgiler sunduğu ifade edilebilir.

Belirlenen ihtiyaçlar doğrultusunda geliştirilen uygulama, birim bazında yapılan satın almalarda harcanan bütçeyi görmeye imkan vermekte, birimlerin satın aldığı malzemeleri ilgili tarih, dönem ve yıl parametrelerine göre sorgulanmasına imkan vermektedir. Birim yetkilileri ve birim sorumluları tarafından hangi ürünlerin daha çok satın alındığı (bir birimde birden fazla yetkili olabilir) veya satın alma dönemleri ve hangi kategorilerdeki ürünlerin daha çok satın alındığı gibi hususlarda sorgulama yapılabilmektedir. Ayrıca iç ve dış denetimi sağlayan birimler için referans kaynak oluşturmaktadır. Satın alma konusunda hangi firmalardan ürünlerin daha yoğun ürün tedarik edildiği, ilgili dönemde ilgili mal ve satın alma hizmeti için ne ödendiği, alternatif hangi firmaların ve tekliflerin var olduğu konusunda bilgi sağlanabilmektedir.

Özveri ve diğerleri (2019) ameliyat malzeme yönetimi 
üzerine gerçekleştirdikleri ve hastane stok yönetimi üzerinde gerçekleştirdikleri çalışmalarında bu yaklaşımın kaynak yönetimi için etkin bir yaklaşım olduğunu ayrıca ifade etmişlerdir. Etkin bir stok ve malzeme yönetimi için malzemelerin maliyet veya kullanım sıklıklarının bilinmesinin de önemli olduğunu, bu şekilde ürün stoklamanın malzeme yönetimini etkinleştireceğini ifade etmişlerdir. Geliştirilen bu sistemin gelece stok öngörüsü için planlama ve performans birimlerine referans veri sağlayacağı göz ardı edilmemelidir. Akan malzeme verisinin aynı zamanda 80/20 kuralının iyi çalıştırılabileceği bir sistem olduğu bu da daha verimli satın alma süreçleri için referans veri taşıyacaktır.

Performans kriterleri için belirlenen hedef ve göstergelerin oluşturulması, performans değerlendirmesi, idare faaliyetlerinin bilgi ve veriye dayalı izlenmesini gerekli kılmaktadır. Bu anlamda, kamu idarelerinin performans esaslı bütçeleme sisteminin gerektirdiği bilgileri toplayacak bir performans bilgi sistemi oluşturmaları gerekmektedir (Maliye Bakanlığı, 2004, s.12). Gerçekleştirilen çalışmanın performansın sözcüğünün içi açıldığında, kurum kaynaklarının daha verimli kullanımına dönük sağlayacağı kayıt bilgi sistemi sayesinde, kurum kaynaklarının yoğun olarak kümelendiği noktaların keşfi, birimlerin harcama kalemlerinin yoğunlukları ve olası iyileştirme veya girişim için kurum içindeki bütçe performans ve planlama birimleri için önemli bir kaynak oluşturacağı ifade edilebilir.

\section{SONUÇ ve ÖNERILER}

Tüm kurumlarda veya kurumların bölüm veya birimlerinde olduğu gibi dijital dönüşüm, bilgi sistemleri, bilginin yönetici için karar destek süreçlerinde ve kurumsal karar verme faaliyetlerinde kullanılması içinde bulunduğumuz çağın bir zorunluluğudur. İdari Mali İşler Daire Başkanlıkları altında iyi kurgulanabilecek veri analiz ekipleri ve kurum kaynaklarının yönetimini sağlayacak etkin bilgi sistemleri yükseköğretim kurumlarını, kaynak yönetimi için faydalı, kurumsal yönetişim için kritik önemde bir araç olacağ ortadadır ve gerçekleştirilen bu çalışma bu amaca hizmet etmektedir.

Türkiye'de 2020-2021 döneminde iki yüzün üzerinde üniversite faaliyetlerini sürdürmektedir. Yükseköğretim kurumları Türkiye'nin barındırdığı genç nüfus da dikkate alındığında ülke geleceği için kritik ve önemli bir noktada yer almaktadır. Bu anlam üniversite kavramının tarihsel süreç içerisinde geçirdiği dönüşüm ve günümüzdeki kritik değeri değerlendirildiğinde ne kadar önemli olduğu görülebilir. Fakat son yıllarda hızla açılan yeni üniversiteler, Türkiye'nin gelişmekte olan kıt kaynaklara sahip bir ülke olduğu gerçeği, yükseköğretim kurumlarında bütçe yönetimini ve harcamaların etkin kullanımının önemini daha da ortaya koymaktadır.

Gerçekleştirilen çalışma, üniversitemizde malzeme tedariki için satın alma süreçlerinde bir karar destek süreci modeli ortaya koymakta ve uzun süre satın alınan ve farklı birim harcamalarının etkin yönetimi için iş zekası modelini çözüm olarak sunmaktadır. İçinde bulunduğumuz dijital dönüşüm çağında ve üretim sektöründeki endüstri 4.0 dönüşümün yaşandığı bu dönemde iş zekası gibi güncel ve yönetici karar destek süreçlerinde kendini kanıtlamış bir teknolojinin üniversite malzeme tedarik süreçlerinde kullanımı gerçekçi ve yerinde bir yaklaşım olarak görülebilir.

Ortaya konulan çalışma bir üniversite için uygulanabilirliği üzerine kurgulanmış ve demo veriler ile gerçekleştirilen raporlama aracı ile olası kazanımları üzerinde bir değerlendirmede bulunulmuştur. Çalışma bu yönüyle kendi gelirleri ile birlikte kamu bütçesinden faydalanan yükseköğretim kurumlarının etkin bütçe yönetimine dikkat çekmektedir. Gerçekleştirilen uygulamanın kamu kurumlarının hem iç hem de dış denetim süreçleri için bilişim sistemlerinin etkin kullanımı için örnek teşkil etmektedir. Literatürde gerçekleştirilen ulusal ve uluslararası tartışmalar ile yükseköğretim kural koyucularının iş zekası gibi güncel teknolojileri kullanarak nasıl daha etkin veri analizi yapabileceği ve veri yönetimi ile etkin kurum yönetimi sağlanabileceği hususunda değerlendirme sunmaktadır.

Türkiye gibi kıt gelişmekte olan ülkeler için kaynakların etkin kullanımı, kaynak yönetimi daha da önemli hale gelmektedir. Özellikle Türkiye'deki yükseköğretim kurumlarının kaynaklarının büyük bir bölümünü kamu ödeneği şeklinde elde ettiği düşünüldüğünde bu noktada geleceğe dönük çok daha fazla araştırmanın yapılması gereği ortadadır. Çalışmada kurum ve birim incelemelerinden çıkarabileceğimiz bir diğer sonuç, sadece merkezi sistemi besleyen uygulamalardan ziyade iki yüzün üzerindeki üniversite için merkezden planlanan, hem merkezdeki kural koyucu ve denetimcilerin ihtiyaçlarını görecek hem de yükseköğretim kurumlarındaki birim yetkililerinin kurumsal kaynak yönetimini etkinleştirecek bir yapılanmanın gerçekleştirmesi gerektiğidir.

\section{KAYNAKÇA}

Ahmad, A. (2015). Business Intelligence for Sustainable Competitive Advantage: in Sustaining Competitive Advantage Via Business Intelligence, Knowledge Management, and System Dynamic. Advances in Business Marketing \& Purchasing. 22(2), 3-220.

Ahmad, A., Abd Razak, R., Osman, W.R.S., Rahmat, A.R.B., 
Abdullah, M.S., \& Ali, A.B.M. (2011). Business intelligence Model for Sustainability of the Malaysian Rural Telecenters. Journal of Southeast Asian Research. 2011(2011), 1-12.

Ateş, H. (2008). Karar Vermede Iş̧ Zekâsının Önemi: Tekstil Sektöründe Bir Araştırma. (Yayınlanmamış Yüksek Lisans Tezi). Dokuz Eylül Üniversitesi Sosyal Bilimler Enstitüsü İşletme Anabilim Dalı Üretim Yönetimi ve Endüstri İşletmeciliği Programı, İzmir.

Bal, T. (2015). Performans Esaslı Bütçeleme PEB Sistemi Çerçevesinde Alternatif Modellerin Türkiye'de Uygulanabilirliği. Journal of Turkish Court of Accounts/Sayıştay Dergisi, (96), 25-54.

Bal, T. (2016). Performans Esaslı Bütçeleme (Peb) Sistemi ve Sistemin Uygulanabilirliğinin Artirilmasına Yönelik Öneriler. Journal of Turkish Court of Accounts/Sayıştay Dergisi, (101), 1-29.

Calitz, A., Bosire, S., \& Cullen, M. (2018). The role of business intelligence in sustainability reporting for South African higher education institutions. International Journal of Sustainability in Higher Education, 19(7), 1185-1203

Damar, M., \& Karaman, D. (2021). Açık Veri ve İş Zekâsı Teknolojisi: İstanbul Büyükşehir Belediyesi Dava Verileri Üzerine Bir Değerlendirme. Mehmet Akif Ersoy Üniversitesi Uygulamalı Bilimler Dergisi, 5(2), 206-228.

Damar, M., Özdağoğlu, G., \& Özdağoğlu, A. (2018). İş zekasını ve ilgili teknolojileri konu alan araştırmalara küresel ölçekte bilimetrik bakış. Bilgi Ekonomisi ve Yönetimi Dergisi, 13(2), 197-217.

Damar, M., Özdağoğlu, G., \& Özveri, O. (2021). Türkiye'de Yükseköğretim Kurumlarının Bilimsel Üretkenliğinin İzlenmesi: Mevcut Durum Analizi ve Öneriler. Yükseköğretim ve Bilim Dergisi, 11(1), 35-48.

Demirel, D. (2015). Performans Esaslı Bütçe: ABD, İngiltere ve Türkiye Örnekleri. Hitit Üniversitesi Sosyal Bilimler Enstitüsü Dergisi, 8(1), 153-176.

DEÜ IMID. (2021). Dokuz Eylül Üniversitesi İdari Mali İşler Daire Başkanlığı Organizasyon Yapısı. Erişim Tarihi: 25/07/2021, https://imid.deu.edu.tr/organizasyon-yapimiz/

Drake, B. M., \& Walz, A. (2018). Evolving business intelligence and data analytics in higher education. New Directions for Institutional Research, 2018(178), 39-52.
Dülger, C., Moğol, T., Çakır T., Yereli, A.B., \& Çetinkaya, Ö. (2012). Devlet Bütçesi. 1. Baskı, Eskişehir: Anadolu Üniversitesi Yayınları.

Ege iMiD. (2021). Ege Üniversitesi İdari ve Mali İşler Daire Başkanlığı Görev Tanımı. Erişim Tarihi: 25/07/2021, https://imidb.ege.edu.tr/tr-

3813/daire_baskani.html

Erüz, E. (2005). Yeni Mali Yönetim Yapısında Performans Esaslı Bütçeleme. XX. Türkiye Maliye Sempozyumu, Pamukkale Üniversitesi, iiiBF Maliye Bölümü. 23-27 Mayıs, ss.61-74.

Fırat, M.S. (2016). Türkiye'de Sosyal Güvenlik Kurumu Bütçesi ve Sosyal Güvenlik Açıları. Türkiye Barolar Birliği Dergisi, 127, 317-338.

Ghobakhloo, M. (2018). The future of manufacturing industry: a strategic roadmap toward Industry 4.0. Journal of Manufacturing Technology Management, 29(6), 910-936.

Gökşen, Y., Aşan H., \& Damar, M. (2015). İşgücü Planlamasinda Bir Karar Destek Sistemi Uygulamasi. Dokuz Eylül Üniversitesi Sosyal Bilimler Enstitüsü Dergisi, 17(1), 53-66.

Gupta, B., Goul, M., \& Dinter, B. (2015). Business intelligence and big data in higher education: Status of a multi-year model curriculum development effort for business school undergraduates, MS graduates, and MBAs. Communications of the Association for Information Systems, 36(1), 23-36.

Guster, D., \& Brown, C. G. (2012). The application of business intelligence to higher education: Technical and managerial perspectives. Journal of Information Technology Management, 23(2), 42-62.

Hartley, K., \& Seymour, L.F.(2010). Towards a framework for the adoption of business intelligence in public sector organisations: the case of South Africa. The Proceedings of the SAICSIT 11, October 3-5, 2010, Cape Town, South Africa.

Hsu, C. W., \& Yeh, C. C. (2017). Understanding the factors affecting the adoption of the Internet of Things. Technology Analysis \& Strategic Management, 29(9), 1089-1102.

iTÜ Bütçe Giderleri. (2021). Bütçe Uygulama Sonuçları Tablosu. Erişim Tarihi: 26/10/2021, https://stratejigelistirme.itu.edu.tr/docs/librariesp rovider163/aylık-mali-tablolar/2021-şubat-malitablolar/2021-şubat-bütçe-uygulama-sonuçlarıtablosu.pdf?sfvrsn=2 
ITÜ IMID. (2021). İstanbul Teknik Üniversitesi İdari ve Mali İşler Daire Başkanlığı, Özgörev. Erişim Tarihi: 25/07/2021, http://www.imid.itu.edu.tr/

Karacan, E. (2010), Performans Esaslı Bütçeleme Sistemi ve Türkiye Uygulaması, Devlet Planlama Teşkilatı Uzmanlık Tezi, Ankara.

KBS. (2021). KBS uygulamaları. Erişim Tarihi 10/06/2021, https://muhasebat.hmb.gov.tr/

Kleesuwan, S., Mitatha, S., Yupapin, P. P., \& Piyatamrong, B. (2010). Business intelligence in Thailand's higher educational resources management. Procedia-Social and Behavioral Sciences, 2(1), 8487.

Köseoğlu, Ö. (2007), Türk Kamu Yönetiminde Değişen Denetim Anlayışı ve Performans Denetimi. Bilâl Eryılmaz, Musa Eken, Mustafa Lütfi Şen (Ed.), Kamu Yönetimi Yazıları, Ankara: Nobel Yayınevi, ss.309-339.

Kurnaz, A. C., (2010). Kamuda Performans Esaslı Bütçe Uygulama Sonuçlarının Değerlendirilmesi ve $\mathrm{Bu}$ Çerçevede Part (Program Assessment Rating Tools) Sisteminin incelenmesi. T.C. Maliye Bakanlığı Strateji Geliştirme Başkanlığı, Mesleki Yeterlilik Tezi, Ankara.

Lee, J. H., Phaal, R., \& Lee, S. H. (2013). An integrated service-device-technology roadmap for smart city development. Technological Forecasting and Social Change, 80(2), 286-306.

Maliye Bakanlığı. (2004). Bütçe ve Mali Kontrol Genel Müdürlüğü, Performans Esaslı Bütçeleme Rehberi (Pilot Kurumlar İçin Taslak), Aralık 2004. https://ms.hmb.gov.tr/uploads/2019/01/Perform ans-Esasl\%C4\%B1-B\%C3\%BCt\%C3\%A7elemeRehberi-Aral\%C4\%B1k-2004.pdf

Mitchell, R., \& Boyle, B. (2010). Knowledge creation measurement methods. Journal of Knowledge Management, 14(1), 67-82.

Mudzana, T., \& Maharaj, M. (2015). Measuring the Success of Business-Intelligence Systems in South Africa: An Empirical Investigation Applying the Delone and Mclean Model. South African Journal of Information Management, 17(1), 1-7.

ODTÜ іMіD. (2021). Orta Doğu Teknik Üniversitesi. Misyon \& Vizyon \& Politikalarımız. Erişim Tarihi: 25/07/2021, https://imidb.metu.edu.tr/tr/misyonvizyonpolitik alarimiz
ODTÜ Mali Tablolar. (2021). 2020 Yılı Kurumsal Mali Durum ve Beklentiler Raporu. Erişim Tarihi: 06/05/2021. http://sgdb.metu.edu.tr/mali-tablolar

Ong, V. K. (2016). Business intelligence and big data analytics for higher education: Cases from UK higher education institutions. Information Engineering Express, 2(1), 65-75.

Özveri, O., Damar, M., \& Durmuş, A. (2019). Ameliyathane Malzeme Yönetim Sisteminin Süreç Yönetimi Tekniği ille Değerlendirilmesi: Bir Üniversite Hastanesi Örneği. Hacettepe Sağlık İdaresi Dergisi, 22(1), 19-50.

Sam, M. (2011). How Should Developing Countries Finance Higher Education?, https://www.academia.edu/1228730/Financing_Hi gher_Education_in__ Developing_Countries $08 / 01 / 2018$

SBB, (2021). Türkiye Cumhuriyeti Cumhurbaşkanlığı Strateji ve Bütçe Başkanlığı, Erişim Tarihi:10/08/20221. http://www.sbb.gov.tr/wpcontent/uploads/2019/02/3-b-2018-2020D\%C3\%B6nemi-Gelir-ve-Net-FinansmanTablolar\%C4\%B1.pdf

Schick, A. (2007). Performance budgeting and accrual budgeting: Decision rules or analytic tools?. OECD Journal on Budgeting, 7(2), 109-138.

Scholtz, B., Calitz, A., \& Haupt, R. (2018). A business intelligence framework for sustainability information management in higher education. International Journal of Sustainability in Higher Education.19 (2), 266-290.

TÜik, (2021). Türkiye İstatistik Kurumu. Erişim Tarihi: 25/07/2021, http://www.tuik.gov.tr/

Uslu, A., \& Ertaş, F.C. (2018). Türkiye'de devlet üniversitelerinin bütçedeki yeri ve performanslarının analizi. Atatürk Üniversitesi iktisadi ve Idari Bilimler Dergisi, 32(4), 979-1007.

Wowczko, I.A. (2013). The Use of BI in Government Driven Environment. Business Intelligence and Data Mining, 29(1), 1107-1111.

Yazıcı, K. (2015). Performans Esaslı Bütçe Sisteminde Yaşanan Sorunlar. Gaziosmanpaşa Üniversitesi Sosyal Bilimler Araştırmaları Dergisi/GOSOS, (Yaz 2015) 10(1), 67-97.

YBYS. (2021). Yükseköğretim Bilgi Yönetim Sistemi. Erişim Tarihi: 25/07/2021, https://istatistik.yok.gov.tr/ 
Zeng, L., Li, L., \& Duan, L. (2012). Business intelligence in enterprise computing environment. Information Technology and Management, 13 (4):297-310.

Zulkefli, N. A., Miskon, S., Hashim, H., Alias, R. A., Abdullah,
N. S., Ahmad, N., ... \& Maarof, M. A. (2015). A business intelligence framework for Higher Education Institutions. ARPN J. Eng. Appl. Sci, 10(23), 18070-18077. 